\title{
Rare Complications of Caudal Epidural Steroid Injections
}

\author{
Ebru Tarıkçı Kılıçç*, Ayhan Kaydu² and Erhan Gökçek ${ }^{2}$ \\ ${ }^{1}$ Department of Anesthesiology, Ümraniye Health Sciences University, Turkey \\ ${ }^{2}$ Department of Anesthesiology, Selahattin Eyyübi State Hospital, Turkey
}

Submission: March 20, 2018; Published: March 26, 2018

*Corresponding author: Ebru Tarıkçı Kılıç, Department of Anesthesiology, Ümraniye Health Sciences University, İstanbul, Turkey, Email: ebru.tarkc@yahoo.com

\section{Opinion}

The caudal epidural steroid injection reported in 1952 helps to treat low back pain. It is a safe and effective tecnique under appropriate fluoroscopic visualization. Caudal epidural steroid injection (CESI) is a minimally invasive procedure includes both cortico steroid and a local anesthetic agent which can reduce inflammation and can be effective when delivered directly into the painful area. However, these injections are not free of complications [1].

Reported side effects are headache, backpain, the increase in blood sugar levels. Rare side effects are; weakness, dizziness, fatigue, skin changes, and osteoporosis. Extremely rare risks include infection, bleeding, dural puncture, a nerve damage, and hiccups.

We observed persist ent hiccups and anosmia lasting for four months after CESI. The patients were treated with totally $20 \mathrm{ml}$ of drug mixture of celestone $6 \mathrm{mgr}(1 \mathrm{cc}$ ) and bupivacaine $15 \mathrm{mgr}$ (3cc) and $16 \mathrm{ml}$ saline solution carefully for backpain. Following these injections anosmia was observed in one patient which resolved spontaneously four months later and persist ent hiccups seen in other patient which treated with chlorpromazine. Computed tomography scans were normal, laboratory results were within normal limits in these patients. The clinical evaluation didn't reveal any pathology.

The possible mechanism of these complications can be explained by the volume effect because this may change the balance of the cerebrospinal fluid volume, pressure, and flow so that anosmia and hiccups can start as a response. We assume that dural sac is compressed as a result of caudal injections. Dural compression lasts at least $30 \mathrm{~min}$ after injection, and the changes of the cerebrospinal fluid lead to these complications $[2,3]$.

Chronic low back pain is a serious health-care and social problem. Caudal epidural steroid injections are one of the frequent used tecniques in managing low back pain. In many studies the effectiveness of caudal epidural steroid injections has been demonstrated. The knowledge of physiology, anatomy, pharmacology, along with accurate placement of injectate under fluoroscopic visualization, can improve patient outcomes.

Anesthesiologists should be aware of complications for caudal epidural injections as epidural steroid injections are increasing day by day. Rare complications must always be on mind.

\section{References}

1. Higuchi H, Adachi Y, Kazama T (2005) Effects of epidural saline injection on cerebrospinal fluid volume and velocity waveform: A magnetic resonance imaging study. Anesthesiology 102(2): 285-292.

2. Kaydu A, Kılıç ET, Gökçek E, Akdemir MS (2017) Unexpected complication after caudal epidural steroid injection: Hiccup. Anesth Essays Res 11(3): 776-777.

3. Dhananni NM, Jiang Y (2012) Anosmia and hypogeusia as a complication of general anesthesia. J Clin Anesth 24(3):231-233. 
This work is licensed under Creative Commons Attribution 4.0 Licens DOI: 10.19080/JHNSS.2018.02.555593

\section{Your next submission with Juniper Publishers will reach you the below assets}

- Quality Editorial service

- Swift Peer Review

- Reprints availability

- E-prints Service

- Manuscript Podcast for convenient understanding

- Global attainment for your research

- Manuscript accessibility in different formats

( Pdf, E-pub, Full Text, Audio)

- Unceasing customer service

Track the below URL for one-step submission https://juniperpublishers.com/online-submission.php 